\title{
Inovasi Pembelajaran Tematik, Kendala dan Upaya Perbaikan dalam Proses Pembelajaran
}

\author{
Laelatul Badriah, Saiful Abibudin, Zunita, Juliyanto \\ Program Studi Pendidikan Madrasah Ibtidaiyah \\ Fakultas Agama Islam Universitas Alma Ata \\ laelatulbadriah0205@gmailcom
}

\begin{abstract}
Abstrak
Proses pembelajaran merupakan serangkaian kegaiatan interaksi antara pendidik, peserta didik dan materi ajara yang diorganisasikan sedemikian rupa untuk mencapai tujuan pembelajaran secara maksimal. Dalam kajian ini merupakan potret pembelajaran tematik yang terjadi di salah satu madrasah ibtidaiyah yang berada di wilayah kabupaten Bantul yaitu MIN 1 Bantul, proses pembelajaran tematik terpotret dengan baik dan sangat inovatif, serta sesuai dengan acuan pembelajaran tematik, dalam hal ini tentunya tidak lepas dengan kendala-kendala yang dihadapi oleh setiap guru kelas, akan tetapi kendala tersebut dapat diatasi dengan berbagai upaya diantaranya menggunakan keterampilan dasar mengajar yang inovatif dan fleksibel, metode dan media yang bervariasi dan inoivatif,dan menyusun perencanaan pembelajaran yang lebih flesibel, serta instrumen evaluasi yang sesuai dengan karakteristik materi dan karakteristik peserta didik.
\end{abstract}

Kata Kunci: pembelajaran tematik, inovatif

\begin{abstract}
The learning process is a series of interactions between educators, students and teaching material organized in such a way as to achieve maximum learning goals. In this study is a portrait of thematic learning that takes place in one Islamic elementary school in the district of Bantul, namely MIN 1 Bantul, the thematic learning process is photographed well and is very innovative, and in accordance with the thematic learning reference, in this case certainly is not free from obstacles - constraints faced by each class teacher, however, these obstacles can be overcome by various efforts including using innovative and flexible teaching basic skills, varied and innovative methods and media, and developing more flexible learning plans, as well as evaluation instruments that are in accordance with material characteristics and characteristics of students.
\end{abstract}

Keywords: thematic, innovative learning

\section{PENDAHULUAN}

Pembelajaran adalah suatu kombinasi yang tersusun meliputi unsur-unsur manusiawi, material, fasilitas, perlengkapan, dan prosedur yang saling mempengaruhi mencapai tujuan pembelajaran. Manusia terlibat dalam sistem pengajaran terdiri dari peserta didik, guru, dan tenaga lainnya, misalnya tenaga labratorium,material meliputi buku-buku, papan tulis, dan kapur, fotografi, slide dan film, audio, dan video tape, fasilitas dan perlengkapan, terdiri dari ruang kelas, perlengkapan audio visual, 
juga komputer, prosedur, meliputi jadwal dan metode penyampaian informasi, praktik, belajar, ujian, dan sebagainya. Rumusan komponen pembelajaran tersebut tidak terbatas dalam ruang data akan tetapi Sistem pembelajaran dapat dilaksanakan dengan cara membaca buku, belajar di kelas atau di sekolah.proses pembelajaran dapat diwarnai oleh organisasi dan interaksi antara berbagai komponen yang saling berkaitan, untuk membelajarkan peserta didik. $^{1}$

Pembelajaran tematik dimaknai sebagai pembelajaran yang dirancang berdasarkan tema-tema tertentu, dengan satu tema memiliki cakupan mata pelajaran lebih dari satu. Pada pembelajaran ini guru diminta keluasan berfikirnya, selain itu guru juga dituntut untuk lebih responsif terhadap peserta didik. Sedangkan peserta didik dituntut untuk lebih aktif, berfikir kritis, serta kreatif dalam menyelesaikan masalah yang disajikan dalam proses pembelajaran. Untuk memenuhi hal tersebut, guru akan lebih banyak belajar tentang metode-metode, pendekatan pembelajaran, strategi, dan media pembelajaran. Namun dalam implementasinya, tidak semua guru dapat melaksanakan pembelajaran tersebut dengan sempurna sesuai dengan apa yang dipelajari.

Dalam hal ini guru merupakan sosok seorang moderator, fasilitator, sekaligus motivator bagi peserta didiknya. Sehingga guru harus mengupayakan pembelajaran di dalam kelas yang aktif, kreatif, dan inovatif demi menggali dan meningkatkan prestasi peserta didik.

Sebagaimana fenomena yang terjadi madrasah taupun di sekolah dalam perencanaan, pelaksanaan, dan penilaian pembelajaran tematik, Perlu diadakan evaluasi intensif dan menyeluruh. Hal ini perlu dilakukan agar guru dapat menemukan cara belajar yang efektif untuk peserta didik, agar dapat mencapai tujuan pembelajaran itu sendiri.

${ }^{1}$ Oemar Hamalik, Kurikulum Dan Pembelajaran, (Jakarta: PT Bumi Aksara, 2011), cetakan ke-12 edisi 1, hlm.57
Berdasarkan uraian di atas peneliti mencoba menarik benang merah yang perlu dikaji lebih mendalam terkait pembelajaran tematik. Dengan demikian perlu diadakan suatu penelitian untuk mengetahui sejauh mana implementasi pembelajaran tematik dan dampak dari implementasi pembelajaran tersebut. Dalam kajian ini peneliti memilih salah satu sekolah yang sudah menerapkan pembelajaran tematik untuk dijadikan lokasi penelitian yaitu Madrasah Ibtidaiyah Negeri (MIN) 1 Bantul. Melalui penelitian ini peneliti berharap akan mendapatkan informasi terkait implementasi pembelajaran tematik beserta kendala-kendala yang terjadi di sekolah. Sehingga dikemudian hari dapat menemukan solusi yang tepat untuk mengatasipermasalahan dan kendalakendala pembelajaran tematik. Selain itu, dari hasil penelitian ini diharapkan dapat menjadi bahan acuan untuk evaluasi pembelajaran tematik di MIN 1 Bantul khususnya, dan di madrasah/sekolah-sekolah lainnya di seluruh Indonesia. Dengan demikian bagaimana proses implementasi dan upaya-upaya untuk mengatasi imlementasinya.

\section{METODOLOGI PENELITIAN}

Penelitian adalah suatu usaha untuk menemukan, mengembangkan, dan menguji kebenaran suatu pengetahuan dan usaha-usaha itu dilakukan dengan menggunakan metode ilmiah. ${ }^{2}$ Pendekatan yang digunakan pada penelitian ini adalah kualitatif. Pendekatan kualitatif adalah prosedur penelitian yang menghasilkan data deskriptif berupa kata-kata tertulis atau lisan orang-orang dan perilaku yang dapat diamati. Pendekatan kualitatif juga memiliki karakteristik alami (natural setting) sebagai sumber data langsung, deskriptif, proses lebih dipentingkan dari pada hasil, analisis dalam penelitian kualitatif cenderung dilakukan secara analisa induktif, dan makna merupakan yang esensial. ${ }^{3}$

${ }^{2}$ Ircham Machfoedz, Metodologi Penelitian Kuantitatif dan Kualitatif (Yogyakarta:Fitramaya,201 4),hlm 1

${ }^{3}$ Lexy J Moleong, Metodologi Penelitian kualitatif, 
Dalam penelitian ini, jenis penelitian yang digunakan adalah penelitian lapangan atau field riset. Dalam metode pendekatan ini, penelitian dilakukan dalam situasi alamiah akan tetapi didahului oleh oleh semacam intervensi (campur tangan) dari pihak peneliti. Intervensi ini dimaksudkan agar fenomena yang dikehendaki oleh peneliti dapat segera tampak dan diamati. Dengan demikian terjadi semacam kendali atau kontrol parsial terhadap situasi di lapangan. ${ }^{4}$

Menurut Sugiyono, populasi adalah wilayah generalisasi terdiri atas objek dan subjek mempunyai kuantitas dan karakteristik tertentu yang diterapkan oleh peneliti untuk dipelajari kemudian ditarik kesimpulannya. ${ }^{5}$ Dalam penelitian ini populasi peneliti adalah peserta didik MIN I Bantul. Sedangkan Sampel adalah sebagian atau wakil dari populasi yang akan diteliti. ${ }^{6}$ Pada penelitian ini teknik penentuan sampling menggunakan purposive sampling. Purposive sampling adalah teknik pengambilan sampel sumber data dengan pertimbangan terentu. ${ }^{7}$ Sampel pada penelitian ini adalah peserta didik kelas II D, III A, dan IV A.

Penelitian ini akan dilaksanakan di MIN I Bantul yang terletak di Jalan Imogiri Timur $\mathrm{km}$ 8.5, Jati, Wonokromo, Pleret, Bantul, Yogyakarta kelas II D, III A, dan IV D pada bulan Februari 2018. Dalam penelitian ini subjek penelitian adalah seluruh warga sekolah, sedangkan untuk menentukan informan peneliti diperoleh dari peserta didik melalui proses pembelajaran. Oleh karenanya subjek penelitian ini adalah peserta didik kelas II D, III A, dan IV A MIN I Bantul tahun ajaran 2018/2019 yang berjumlah 87 peserta didik terdiri dari 44 peserta didik laki-laki dan 43 peserta didik perempuan dan tiga guru kelas.

(PT Remaja Roesdakarya: Bandung,2014).hlm. 3.

${ }^{4}$ Saifuddin Azwar, Metode Penelitian, (Yogyakarta: pustaka pelajar, 1998), cet-ke 1,hlm.21.

${ }^{5}$ Sugiyono, Statistik Untuk Penelitian, (Bandung: Alfabeta,2007),hlm.55.

${ }^{6}$ Saifuddin Azwar, Metode Penelitian, (Yogyakarta: Pustaka Pelajar,1998),cet-ke 1,hlm. 79.

${ }^{7}$ Sugiyono, Statistik untuk penelitian..., hlm.124.
Teknik pengumpulan data merupakan langkah yang paling utama dalam penelitian, karena tujuan utama dari penelitian adalah mendapatkan data. Tanpa mengetahui teknik pengumpulan data, maka peneliti tidak akan mendapatkan data yang memenuhi standar data yang ditetapkan. Teknik penelitian yang digunakan untuk pengumpulan data pada penelitian ini adalah : observasi, Wawancara, dan dokumentasi. Sedangkan Instrumen penelitian yang digunakan pada penelitian ini adalah panduan observasi dalam proses pembelajaran dan lingkungan sekolah, panduan wawancara secara mendalam yang bersifat fleksibel dalam bentuk poin-poin pertanyaan dari indikator penelitian dan dokumen-dokumen lainya yang terlibat.

Data yang digunakan dari beberapa sumber seperti wawancara, observasi dan dokumentasi, selanjutnya data memasuki tahap pengujian keabsahan. Tekhnik keabsahan data menggunkan metode triangulasi yakni tekhnik pengumpulan data yang berbeda-beda untuk mendapatkan data dari sumber yang sama. Pengujian dilakukan dengan cara mengecek data dari sumber yang sama dengan teknik pengumpulan data yang berbeda ${ }^{8}$.

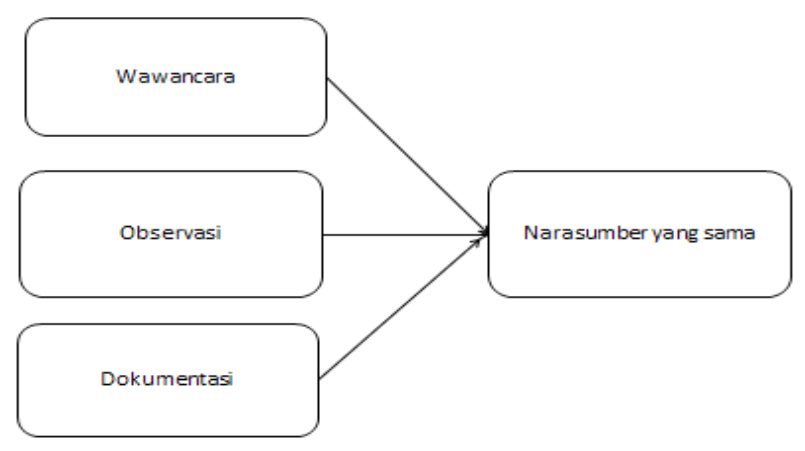

Gambar 1. Triangulasi teknik pengujian data menggunakan 3 metode berbeda dengan satu narasumber ${ }^{9}$

Analisis data adalah proses mencari dan menyusun secara sistematis. Data yang

\footnotetext{
${ }^{8}$ Sugiono, Metode Penelitian Managemen, (Bandung: Alfabet, 2014), hlm.412

${ }^{9}$ Ibid.., hlm.372
} 
diperoleh saat wawancara, observasi, dan dokumentasi akan diorganisasikan, dengan cara mengorganisasikan kedalam kategori, menjabarkan kedalam unit-unit, melakukan sintesis, menyusun kedalam pola, memilih mana yang penting dan mana yang akan dipelajari, dan membuat kesimpulan sehingga mudah dipahami oleh diri sendiri maupun orang lain ${ }^{10}$.

Dalam penelitian ini, analisis data yang digunakan adalah analisis data deskriptif kualitatif. Penelitian deskriptif adalah penelitian yang berusaha mendeskripsikan suatu gejala, peristiwa, kejadian yang terjadi saat sekarang. Penelitian deskriptif memusatkan perhatian kepada masalah-masalah aktual sebagaimana adanya pada saat penelitian berlangsung.

Melalui penelitian deskriptif ini peneliti berusaha mendeskripsikan peristiwa dan kejadian yang menjadi pusat perhatian tanpa memberikan perlakuan khusus pada peristiwa tersebut. ${ }^{11}$ Sugiyono mengemukakan bahwa aktifitas dalam analisis data kualitatif dilakukan secara interaktif dan berlangsung secara terus menerus sampai tuntas sehingga datanya sudah jenuh. Aktifitas dalam analisis data yaitu data reduction, data display dan conclusion drawing /verification. ${ }^{12}$

\section{PEMBAHASAN}

\section{Implementasi Pembelajaran Tematik}

Berdasarkan hasil penelitian terdapat beberapa poin dalam pelaksaan pembelajaran tematikyang terjadi di MIN1 Bantul. Secaraumum pembelajaran di MI N 1 Bantul alhamdulillah berjalan baik dan lancar, walaupun terdapat kekurangan dalam penyusunan administrasi pembelajaran maupun proses pembelajaran. Berdasarkan hasil observasi dan wawancara guru MIN 1 Bantul sebelum melakukan

${ }^{10}$ Nana Syaodih Sukmadinata, Metode Penelitian Pendidikan, (Bandung: Remaja Roesdakarya, 2008), hlm.220

${ }^{11}$ Asmani Ma'mur Jamal, tuntunan lengkap metodologi praktis penelitian pendidikan (Jogjakarta:Diva Press, 2011),hlm.75

${ }^{12}$ Sugiyono, Metode Penelitian Pendidikan, (Bandung: Alfabeta,2012),hlm.337. kegiatan pembelajaran, terlebih dahulu harus melakukan komunikasi atau musyawarah untuk melakukan persaman persepsi dalam proses pembelajaran. Selain wawancara juga dilakukan observasi pembelajaran, ketika observasi guru menerapkan ketrampilan-ketrampilan mengajar dalam kegiatan pembelajaran, serta melaksanakan sesuai yang ada di buku siswa maupun di buku guru.

Persiapan perangkat pembelajaran yang harus disusun sebelum melakukan proses pembelajaran, secara garis besar terpenuhi. Diantaranya Silabus dan RPP yang dapat dijadikan Sebagai pedoman pembelajaran, RPP ini berfungsi sebagai kendali dalam proses pembelajaran yang terjadi di kelas. Hal ini sesuai dengan Deni Kurniawan mengemukakan RPP berfungsi untuk menghindari terjadinya proses pembelajaran yang acak. ${ }^{13}$

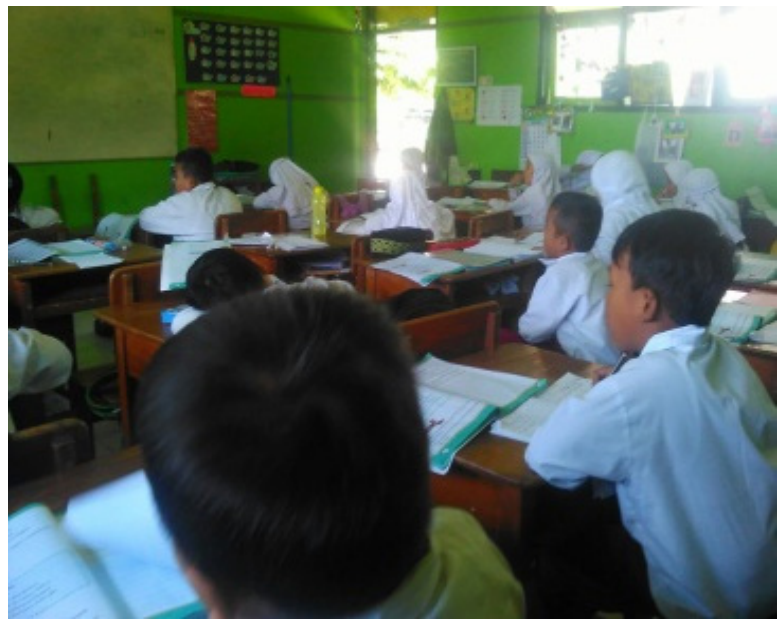

Gambar 2. Proses pembelajaran tematik kelas $2 \mathrm{~d}$

Hasil proses pembelajaran tematik yang dilaksanakan selama empat kali pertemuan melalui tiga tahap kegiatan dalam proses pembelajaran yakni kegiatan awal (pembukaan), inti, dan akhir (penutup). Secara garis besar pelaksanaan kegiatan pembelajaran berdasarkan pada petunjuk yang ada di buku guru yang sudah diadaptasi dalam bentuk RPP. Jika ada kekurangan waktu dan materi masih cukup banyak dalam melaksanakan kegiatan

${ }^{13}$ Deni Kurniawan, Pembelajaran Tematik Terpadu (Teori, Praktik dan Penilaian), (Bandung: Alfabeta.2014) cet-ke 1, hlm.123. 

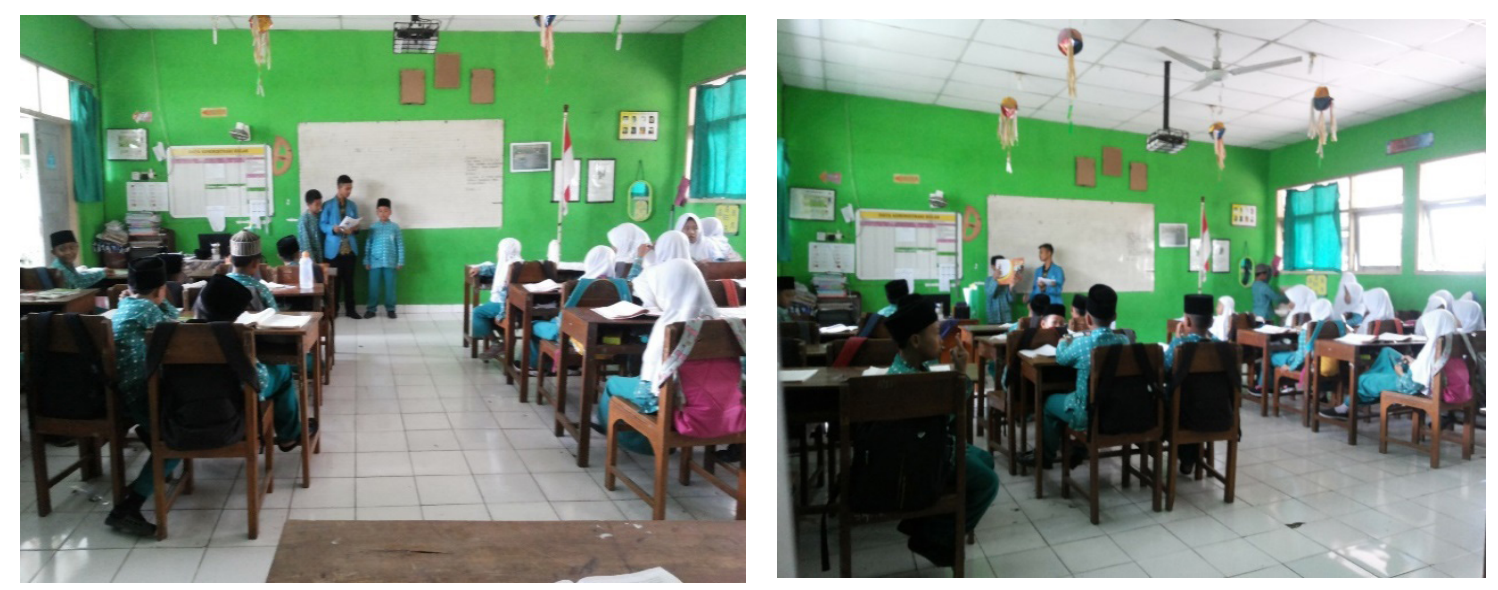

Gambar 3. Kegitan pembelajaran tematik kelas 4d

pembelajaran, maka perlu adanya antisipasi dengan pemberian tugas rumah, yang dapat diambil dari latihan-latihan pada buku siswa.

Proses pembelajaran tematik telah menggunakan berbagai metode dan strategi pembelajaran yang sesuai dengan karakteristik peserta didik dan karakteristik materi ajar. Diantara metode yang digunakan diantaranya metode ceramah, tanya jawab, penugasan, praktik, demonstari, proyek dan diskusi kelompok. Seperti pada saat pembelajaran SBdP tentang "Menirukan gerakan burung dan ayam", metode yang digunakan adalah praktik, hal ini dikarenakan ketika peserta didik mempraktikan secara langsung, peserta didik akan lebih mudah faham dibandingkan hanya dengan diangan-angan. Hal ini sesuai dengan teori kognitif Piaget.

Menurut Piaget (perkembangan kognitif seseorang mengikuti beberapa tahap salah satunya yaitu: Tahap/periode ketiga (umur 7 - 11 tahun). Pada tahap ini anak sudah dapat melakukan berbagai macam tugas yang konkrit. Anak mulai mengembangkan 3 operasi berpikir, yaitu: Identifikasi: mengenali sesuatu, Negasi: mengingkari sesuatu, Reprokasi: mencari hubugan timbal balik atara bebrapa hal. ${ }^{14}$

Untuk mendinginkan pembelajaran dapat digunakan metode ice breaking sebagai selingan sementara dalam kegiatan pembelajaran dengan

${ }^{14}$ Sunarto dan Agung Harton, Perkembangan Peserta Didik, 2008, tujuan peserta didik tidak spaneng, selain itu hal ini untuk tetap menjaga kehangatan peserta didik serta untuk tetap menjaga semangat belajar pada peserta didik. Seperti ketika kelas mulai gaduh biasanya dapat memberikan seruan kata "Hallo" dan peserta didik menjawab "Hai"yang bertujuan agar peserta didik kembali tenang. Selain itu dapat juga dilakukan dengan gerakan tepuk tangan misalnya 'Tepuk satu, Tepuk dua, Tepuk tiga”. Ice breaking ini dapat digunakan sesuai dengan kondisi peserta didik didalam kelas.

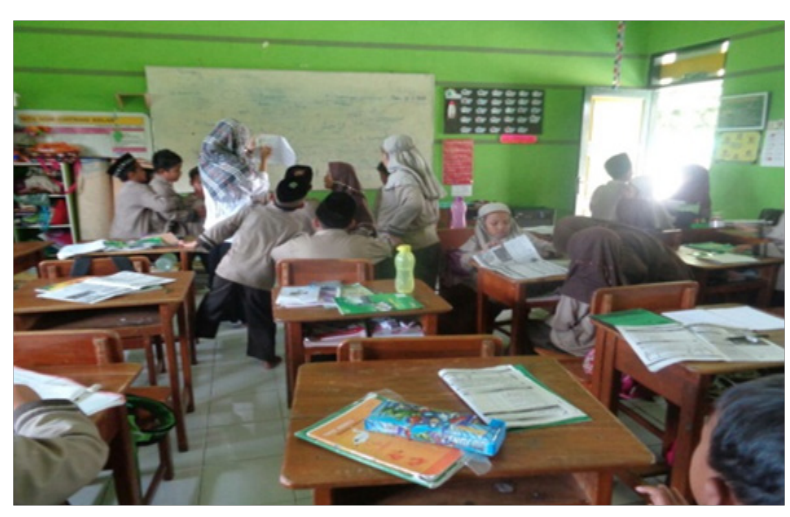

Gambar 4. Proses pembelajaran tematik inovasi metode pembelajaran

Proses pembelajaran tematik juga membutuhkan kesiapan media pembelajaran yang dapat memberikan semangat dan motivasi peserta didik sehingga terjadi proses pembelajaran berjalan lebih aktif. Pendidik atau guru dapat membu at media pembelajaran yang 

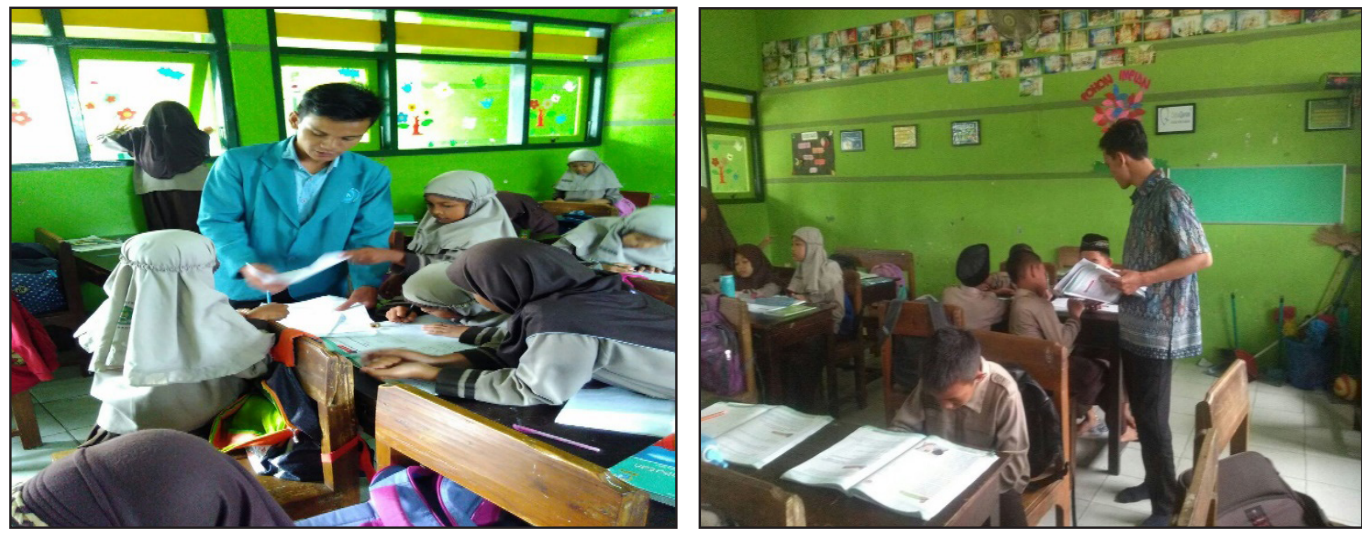

Gambar 5. Kegitan pembelajaran tematik yang inovatif di kelas 3a

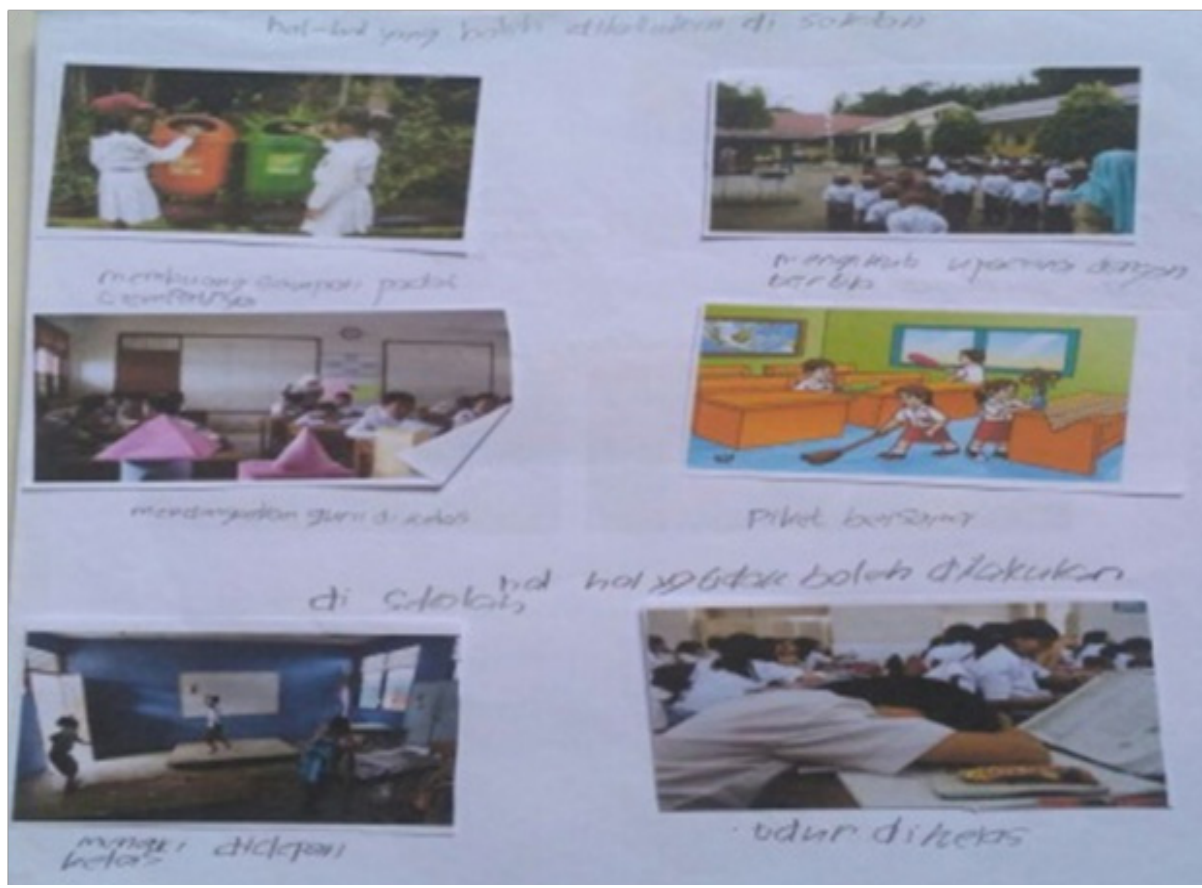

Gambar 6. Media Pembelajaran Tematik yang inovatif di Kelas 2

lebih menarik perhatian peserta didik. Seperti saat materi berat timbangan, dapat mengunakan media pembelajaran 3 dimensi yang familiar dengan peserta didik dan memanfaatkan bendabenda yang ada disekitar peserta didik. Seperti jam dinding yang dapat dimanfaatkan sebagai jarum timbangan.

Pada tahap akhir pembelajaran tematik perlu dilakukan evaluasi pada setiap akhir pertemuan sebagai tolak ukur keberhasilan proses pembelajaran. Evaluasi ini dapat berupa latihan soal, pretest maupun post test yang ada di buku siswa dan sumber lainnya.
Dalam melaksakan proses pembelajaran tematik guru atau pendidik dapat menggunakan ketrampilan-ketrampilan dasar mengajar secara terintegrasi dalam kegiatan pembelajaran. ketrampilan-ketrampilan tersebut meliputi ketrampilan membuka dan menutup pelajaran, ketrampilan mengkoordinasi kelas, ketrampilan menjelaskan, ketrampilan bertanya, ketrampilan mengelola kegiatan kelompok, ketrampilan memberikan penguatan, dan lain-lain. Selain menggunakan keterampilan dasar mengajar seorang guru juga perlu melakukan refleksi hasil pembelajaran dan menindaklanjutinya dalam bentuk perbaikan pembelajaran. 


\section{Kendala Dalam Implementasi Pembelajaran Tematik}

Implementasi pembelajaran tematik di kelas II D, III A dan IV A tidak terlepas dari hambatan. Hambatan ini muncul kerena situasi kelas tidak sesuai . Beberapa hambatan yang muncul dalam implementasi pembelajaran tematik sebagai berikut : Adanya beberapa peserta didik yang kurang antusias dalam mengikuti kegiatan belajar mengajar, sehingga cenderung mencari perhatian dan membuat gaduh. Hal itu mengganggu kegiatan belajar mengajar. Kurang bisa mengkondisikan kelas. Dan Proses pembelajaran ada beberapa yang tidak sesuai dengan rencana pelaksanaan pembelajaran, karena kondisi kelas yang tidak memungkinkan. ${ }^{15}$

Selaian selain kendala tersebut juga ada beberapa kendala lain juga diantranya kesulitan dalam pengkondisian kelas, kesulitan dalam menangani siswa yang ramai pada waktu pelajaran, kesulitan terhadap siswa yang iri dengan temannya yang mendapat perhatian lebih, kesulitan membagi perhatian kepada siswa, kesulitan dalam pemberian nilai, kesulitan dalam memanagemen waktu, dan kesulitan dalam mengevaluasi kegiatan pembelajaran. ${ }^{16}$ hal ini terjadi disebabkan keadaan kelas yang aktif. Pembelajaran tematik sangat efektif untuk meningkatkan keaktifan peserta didik dalam proses pembelajaran. Keefektifan pembelajaran tematik dapat meningkatkan keaktifan peserta didik, keadaan ini terlihat dari karakteristik pembelajaran tematik dan karakteristik peserta didik yakni dengan cara memusatkan pembelajaran pada peserta didik. ${ }^{17}$

\footnotetext{
${ }^{15}$ hasil observasi pembelajaran kelas bawah di MIN 1 Bantul

${ }^{16}$ Kondisi pembelajaran di kelas IIIA dalam proses pembelajaran tematik

${ }^{17}$ Zaenul amry dan laelatul badriah, Pembelajaran Tematik Sebagai Upaya Meningkatkan Keaktifan Peserta Didik ELEMENTARY: Islamic Teacher Journal Vol. 6 No. 2 dapat diakses http://journal.stainkudus.ac.id/index. php/elementary/article/view/4388/2854
}

Adapun yang terjadi di kelas atas diantaranya pemahaman karakteristik peserta didik, sehingga masih ditemukan ketidak tepatan dalam memilih media dan metode pembelajaran. Oleh karena itu, perlu adanya inovasi pembelajaran secara kontinu dan langsung pada subjek pembelajaran dan peserta didik, yang usianya sudah mampu berfikir abstrak meskipun belum sempurna, sehingga perlu diberikan kejelasan pada saat awal bab dan setiap awal pertemuan disaat mengajarkan materi dan menjawab pertanyaan-pertanyaan tak terduga. ${ }^{18}$

\section{Upaya Mengatasi Kendala Dalam Implementasi Pembelajaran Tematik}

Dari hasil penelitian dapat ditarik beberapa upaya yang dapat dilakaukan dalam menhadapi kendalam proses pembelajaran tematik dintaranya:

a. Di berikan pertanyaan sesuai materi yang disampaikan, agar menarik perhatian supaya tidak gaduh sendiri dan diberikan hadiah jika dapat menjawab pertanyaan.

b. Perbanyak menggunakan media yang inovatif, karena siswa lebih antusias jika menggunakan media yang inovatif dan mudah difahami.

c. Membuat cadangan RPP, jika RPP telah dinyatakan akan digunakan tidak sesuai, maka dapat menggunakan RPP yang lainnya yang lesesuai dan tetap dengan kondisi dan karate peserta didik.

d. Memberikan kebebasan terhadap peserta didik dalam kegiatan pembelajaran. Bebas di sini bukan bersifat bebas tanpa aturan tetapi tetap dikontrol dan tetap dalam pengawasan serta adanya pemberian tugas yang harus diselesaikan. Adanya kegiatan intermezzo atau selingan-selingan sementara.

e. Mendekati salah satu peserta didik yang paling ribut dan berdiri didekatnya serta memperhatikan kerjanya lali Menyakan ulang yang saya jelaskan kepada siswa yang ramai.

\footnotetext{
${ }^{18}$ Kondisi pembelajaran dikelas IV A dalam proses pembelajaran.
} 
f. Memberikan pengertian terhadap siswa tersebut dan memberikan sikap yang sama terhadap semua siswa.

g. Melakukan pembelajaran kelompok, dan berusaha mendekati setiap kelompok, serta memberikan penguatan-penguatan verbal maupun non verbal pada setiap kelompok.

h. Menentukan kriteria penilaian terhadap hal yang akan dinilai.

i. Membuat rencana pengajaran (RPP) dan membuat skenario pembelajaran, serta membuat rencana-rencana tambahan.

Dari beberapa upaya di atas terdapat beberapa poin yang dapat diupayakan menjadi solusi bagai permasalah pembelajaran yaitu dengan menyusun rencana pembelajaran dengan memahami karakteristik peserta didik, karakteristik materi ajar, RPP yang fleksibel, menyusun media dan materi ajar sesuai dengan karakteristik peserta didik, metode dan strategi pembelajaran yang inovatif, kemampuan keterampilan mengajar, dan kemampuan menginovasi pembelajaran dengan beberapa keterampilan dalam mendukung pembelajaran seperti menggunakan Ice breaking dalam mendinginkan proses pembelajaran. prose pembelajaran tematik menekankan pada tiga ranah hasil belajar dengan cara selalu mendorong dan memotivasi peserta didik untuk ikut serta melakukan aktivitas - aktivitas pembelajaran baik di kelas maupun d luar kelas yang mengarah sikap, kognitif dan keterampilan ${ }^{19}$ sebagai capaian hasil belajar peserta didik di kahir capaian kompetensi sesuai dengan kurikulum yang telah ditetapkan.

\section{KESIMPULAN}

Implementasi pembelajaran tematik yang diterapkan di MIN 1 Bantul sesuai dengan prosedur yang ada, yaitu adanya

${ }^{19}$ Laelatul Badriah, Implementasi Pembelajaran Tematik Berdasarkan Standar Proses Pendidikan di Madrasah Ibtidaiyah, jurna Literasi (Jurnal Ilmu Pendidikan), volume 9 no. 2 2019. dapat di akses https:// ejournal.almaata.ac.id/index.php/LITERASI/article/ view/883/1047, hlm. 77-89 perencanaan yaitu persipan silabus dan RPP yang matang dengan kelengkapan komponen RPP yang memadai, pelaksanaan dan penilaian berdasarkan kebutuhan dan karakteristik peserta didik dengan memperhatikan tiga ranah pembelajaran kognitif afektif dan psikomotorik. Adapun beberapa kendala yang diahadapi ketika mengimplementasikan pembelajaran tematik adalah kesiapan peserta didik, ketidak sesuai RPP dengan proses pemebelajaran, kurang sesuainya media dan metode yang digunakan guru dalam proses pembelajaran dengan karakteristik peserta didik, keterbatasan dalam menginovasi proses pemelajaran. Dengan demikian dapat diupayakan dengan beberapak kegiatan dalam rangka meminimalisir kendala yang digadapi oleh guru kelas dalam proses pembelajaran tematik, diantaranya adalah memberikan pertanyaan pada peserta didik dalam proses pembelajaran yang akan membawa ke arah kejenuhan peserta didik, menggunkan keterampilan dasar mengajar yang fleksibel, menyususn renacana Pembelajaran yang fleksibel dan tidak hanya satu, menentukan instrument penilaian beserta rubriknya.

\section{DAFTAR PUSTAKA}

Asmani Ma'mur Jamal. 2011. Tuntunan Lengkap Metodologi Praktis Penelitian Pendidikan. Jogjakarta: Diva Press.

Deni Kurniawan. 2014. Pembelajaran Tematik Terpadu (Teori, Praktik dan Penilaian) cet. 1. Bandung: Alfabeta.

Ircham Machfoedz. 2014. Metodologi Penelitian Kuantitatif dan Kualitatif Yogyakarta:Fitramaya.

Laelatul Badriah, Implementasi Pembelajaran

Tematik Berdasarkan Standar Proses Pendidikan di Madrasah Ibtidaiyah, jurna Literasi (Jurnal Ilmu Pendidikan), volume 9 no. 2 2019. dapat di akses https://ejournal. almaata.ac.id/index.php/LITERASI/article/ view/883/1047

Lexy J Moleong. 2014. Metodologi Penelitian kualitatif. PT. Remaja Roesdakarya: Bandung. 
Nana Syaodih Sukmadinata. 2008. Metode Penelitian Pendidikan. Bandung: Remaja Roesdakarya.

Oemar Hamalik. 2011. Kurikulum Dan Pembelajaran, cetakan ke-12 edisi 1. Jakarta: PT Bumi Aksara.

Saifuddin Azwar. 1998. Metode Penelitian. Yogyakarta: pustaka pelajar, 1998.

Sugiyono. 2007. Statistik Untuk Penelitian. Bandung: Alfabeta .2012. Metode Penelitian Pendidikan. Bandung: Alfabeta
2014. Metode Penelitian Managemen. Bandung: Alfabet.

Sunarto dan Agung Harton. 2008. Perkembangan Peserta Didik. Jakarta

Zaenul amry dan laelatul badriah, Pembelajaran Tematik Sebagai Upaya Meningkatkan Keaktifan Peserta Didik ELEMENTARY: Islamic Teacher Journal Vol. 6 No. 2 dapat diakses http://journal.stainkudus. ac.id/index.php/elementary/article/ view/4388/2854 